\title{
Portrait of a Teacher of Educators Prof. Dr. Orhan Okay as a Role Model
}

\author{
Tacettin ŞIMŞEK ${ }^{1} \&$ M. Abdullah ARSLAN ${ }^{2}$ \\ ${ }^{1}$ Kazım Karabekir Faculty of Education, Ataturk University, Erzurum, Turkey \\ ${ }^{2}$ Faculty of Education, Erzincan Binali Yildirim University, Erzincan, Turkey \\ Correspondence: M. Abdullah ARSLAN, Faculty of Education, Erzincan Binali Yildirim University, Erzincan, \\ Turkey. E-mail: mabdullaharslan@hotmail.com
}

Received: December 21, 2020

doi:10.5539/ies.v14n5p95

\author{
Accepted: February 17, 2021 \\ Online Published: April 26, 2021 \\ URL: https://doi.org/10.5539/ies.v14n5p95
}

\begin{abstract}
In education, the importance of effective and behavioral transfer besides cognitive information is a fact. In this sense, an educator is expected to be an example in terms of his behaviors as well as transferring his knowledge to the students. The best way to raise good students and form the desired behavior in them is the educators who personally touch the lives of their students being role models. In the Turkish academic world, M. Orhan Okay has a remarkable place not only with his scientific studies but also with his "human work" upbringing style. This study is carried out with document analysis which is one of the qualitative research methods. In this study, it is underlined that Okay is a role model/an ideal educator, further every aspect of his ideal educationalism, which complements his exemplary scientist identity, is emphasized. In this respect, besides being a well-equipped scientist, he showed his students and the whole academic environment how an example of an ideal / role model should be. In either way, he expected his students to do what he did personally (as an exemplary person in the academic and non-academic world). In conclusion, it is hoped that the educator deformation which has increased in recent years will disappear to a certain extent thanks to exemplary educators like Professor Okay.
\end{abstract}

Keywords: academic educator, ideal educator, Orhan Okay, students

\section{Introduction}

Educational activities provide the basis for the transfer of emotions, thoughts, and behaviors beyond the transfer of knowledge. In this context, the educator is expected to be a model in terms of behaviors as well as conveying the wealth of mind to his students.

The term "role model" draws on two prominent theoretical constructs: the concept of role and the tendency of individuals to identify with other people occupying important social roles (Bell, 1970); and the concept of modeling, the psychological matching of cognitive skills and patterns of behavior between a person and an observing individual (Bandura, 1977; Wood \& Bandura. 1989). These two aspects of role models reflect two different theoretical traditions. The first, role identification theories, emphasize the notion that individuals are attracted to people whom they perceive some similarity to, in terms of their attitudes, behaviors, goals, or the desirability of their status position, and are motivated to enhance that similarity through observation and emulation (Erikson, 1950; Foote, 1951; Kohlberg, 1963). The second, social learning, or modeling theories, suggest that individuals attend to models because they can be helpful in learning new tasks, skills, and norms (Bandura, 1977; Wood \& Bandura, 1989). Identification theories, then, place relatively more emphasis on the motivational and self-definitional aspects of role models (Flum, 2001; Foote, 1951), while modeling theories emphasize the learning aspects.

The traditional idea of a role model is that of a person in an influential role position, such as a parent, teacher, supervisor or mentor, who provides an example for individuals to imitate (e.g., Erikson, 1985).

The popular media reflect and encourage this scholarly view, suggesting that career success is caused by a person having "good role models" and career failure by a "lack of role models" (Girona, 2002). Individuals are urged to seek role models who can help them achieve their goals (Lockwood \& Kunda, 1997), and leaders of organizations are, in turn, urged to be role models for their employees (Deal \& Kennedy, 1982; Gibson,2004).

In the social learning system, new patterns of behavior can be acquired through direct experience or by observing 
the behavior of others.

During the course of learning people not only perform responses but they also observe the differential consequences accompanying their various actions. On the basis of this informative feedback, they develop thoughts or hypotheses about the types of behaviour most likely to succeed (Bandura, 1977).

"They are not entities that merely watch the brain mechanisms driven by environmental events. Affective, motor and brain-related systems are tools that people use to achieve goals that give direction and meaning to their lives" (Bandura, 1999). People are producers of thoughts that have decision-making functions. They plan their future actions to adapt to changing situations, evaluate the functional aspects of their actions, organize strategically chosen choices, and evaluate the possible consequences of their actions (Bandura, 1999).

Accordingly, the general principles of social learning theory can be listed as follows (Rutledge, 2000): 1. People can learn by observing the behavior of others and the consequences of these behaviors. 2. Learning can occur without a change in behavior. While behaviorists think that learning must bring about a permanent change in behavior; According to the advocates of social learning theory, the reflection of learning on performance (behavior) is not necessary because people can learn only by observing. Learning may or may not bring about a change in behavior. 3. Perception plays an important role in learning. In the last 30 years, social learning theory has increasingly approached human learning process perceptually (cognitively). Awareness of future reinforcers or punishments and expectations about them have a significant impact on human behavior. 4 . Social learning theory can be considered as a bridge or transition between behavioral and cognitive learning theories.

\section{Positive Role Model}

Refers to a role model having attributes which are perceived by the individual as similar, are admired and sought out for possible emulation.

Negative Rol Model

Refers to a role model having attributes which are primarily observed by the individual as examples of how not to behave in a particular context.

Global Role Model

Refers to a variety of attributes in a role model which are attended to by the individual, including skills, traits, and behaviors.

\section{Specific Role Model}

Refers to a single or small set of attributes in a role model which are attended to by the individual (Hiralaal, December 2018).

One of the basic elements that make up the school culture are heroes. Heroes are expressed as deceased or living, real or imaginary persons with highly appreciated characteristics within an organization. In this respect, heroes are role models of an organization. Organizations with strong and influential cultures keep alive, commemorate and celebrate the organizational heroes who represent the fundamental values of the organization with their thought, behavior, personality and achievements (Elkatmıs, 2016, p. 55).

Deal and Kennedy (1982) found that male and female protagonists serving an organization play a role in six ways. Providing achievable and humanitarian success, providing role models, symbolizing the organization for the external environment, protecting the organization's special appearance, setting performance standards and motivating employees. If values are the essence of culture, then heroes constitute the living example of these values and the embodiment of the power of the organization. Heroes are very important figures of a strong culture. They are role models for employees. Heroes are symbolic figures with unusual actions; they demonstrate the ideal of success inherent in the human capacity.

While analyzing behavior in terms of education, it is handled in three areas of behavior: Cognitive, affective, and psychomotor. Cognitive behaviors are associated with the mind, affective behaviors are associated with the heart, and psychomotor behaviors are associated with the body (Bacanll, 2007, p. 264).

Aydinay Satan (2015) under the title of "The relationship between value preferences and attitudes towards the teaching profession" states that in many studies conducted on teacher qualifications, teachers' personality traits, values, behaviors, attitudes, interests, and academic characteristics play an important role in the teaching and learning process. In the continuation of the same article, it is said that the common goal of education faculties is to train effective and qualified teachers. Teacher candidates who have acquired positive attitudes means qualified teachers. It is also explained that in higher education institutions that train teachers, it is extremely important to 
include approaches that provide teacher candidates with knowledge and skills as well as the appropriate attitudes and behaviors required by the teacher (p. 999).

Schools have an important role in helping individuals acquire, develop and maintain positive behavioral tendencies. For this, first of all, teachers must have the competence to understand the moral or value dimension of education, to internalize it, and to transfer these to students. Teachers are one of the leading elements that will guide students in gaining values in school education. It is an obvious fact that teachers should be exemplary models that reflect the values accurately in the school environment and outside, and they should make students do various practices to realize the desired learning about values both inside and outside the classroom by using strategies. Naturally, the students who will be educated by teachers who are well-equipped in value education will gain moral values and will make the necessary contributions both to their existence and to the society they live in (Hökelekli, 2011, p. 293).

A virtue is socially valued, while a moral virtue, such as honesty, is morally valued. According to Lickona (1991), schools and teachers should educate for character, specially through teaching respect and responsibility.

Teachers focus on cognitive strategies and strategies for critical thinking. They play a role both as a participant and a guide in the transfer of values in the classroom (Veugelers, 2000, p. 41).

Again, in many countries, one of the important tasks of teachers is to pass on basic value moral standards to future generations (Kirschenbaum, 1994, p. 3).

Teachers who want to change the values of students at school should model these values. Likewise, teachers help students to understand school policies by reinforcing behaviors consistent with basic values as a model (Ulusoy \& Dilmaç, 2012, p. 94). Satı Bey states that the biggest task of creating a strong will in children from a young age falls on the teachers. The teacher should be an example to the students by being determined, and confident. Teachers should not allow bad feelings to arise in order to place good feelings and tendencies in children and remove the bad ones, and they should create environments that will provide good feelings (Ulusoy \& Dilmaç, 2012, p. 97).

According to the "ideal educator approach", one of the approaches expressed in the literature on the education of the child's value and character, educators who are strong-willed, open-minded, capable of understanding and evaluating various dimensions of social and moral relations should find the opportunity to deal with each child individually at school and everywhere, remove the potentially harmful forces from the student's environment and arrange his feelings and tendencies with factors that will positively affect his emotions and tendencies (Kaymakcan \& Meydan, 2016, p. 243).

A teacher who will be a moral guide is a person who treats students with respect and love, sets a good example, supports behaviors for the benefit of society, and corrects offensive behaviors. Teachers should show interest, be a model and guide students by caring for them, without making any distinction between students, choosing favorites, not snapping or ridiculing them, degrading or damaging their self-confidence (Kaymakcan \& Meydan, 2016, p. 244).

It is a well-known fact that the good teacher plays an important role in raising the new generation, naturally in the future of the country. A teacher, who only assumed the role of transferring knowledge of the last century, has become unable to respond adequately to today's needs. Social, economic, cultural, and international change and problems have increased the need for new interpretations and new perspectives on the concept of "teacher". A good teacher is not just the teacher who keeps the classroom quiet and keeps students in a learning environment. The role of the teacher in education is seen as important, which cannot be underestimated. The teacher is the person who trains all the citizens and expert staff of the country, transfers the existing culture to new individuals, and enables the individual to socialize in this way. At the same time, $\mathrm{s} /$ he should be sufficient to have the necessary professional knowledge, skills and attitudes (Boran, 2014, p. 407).

In order for the teacher to be honest, ethical, altruistic, responsible, have cultural and social values, and be equal and fair to their students, teachers need to teach their students that value is a choice and societies are made up of people with similar preferences. Further, It is thought that it would be beneficial to add a course on values education to the curriculum of faculties in order to prioritize approaches that will raise awareness by considering national and universal values together, emphasizing common values and gaining the awareness that value differences are richness instead of value transfer in the education process (Boran, 2014, p. 408).

Teacher educators, through their role modeling, should encourage student teachers to take control of their lives and become pioneers of change so that they grow into effective teachers (Rust, 2019). First, good teacher educators embody theoretical ideas and principles, that is, they seek to "practice what they teach" to ensure their pedagogy is 
consistent with their purposes as educators and with current learning theories. Second, good teacher educators provide a vision of the possible... Third, good teacher educators inspire those entering the profession (Rust, 2019, pp. 14-15).

Roles of a good teacher include knowledge, creator planner and provider, facilitator of learning, class manager and resources generator, assessor, and role model. The roles of a teacher are not static but dynamic as these continue changing as per the demands of the society (Lumpkin, February 2008).

Based on all these data, an ideal educator is an important model in terms of her upbringing, the formation of his/her personality, research, analysis, behavior towards his/her students, and social relations for everyone, especially his/her students at school and outside of school. Acting without arrogance, on the contrary, by glorifying others; $\mathrm{S} /$ he is a role model both cognitively, affectively, and behaviorally.

In this study, based on what is written about him in many sources, Prof. Dr. M. Orhan OKAY, both as a personality and a scientist, is an exemplary researcher and human being with his cognitive, affective, and behavioral aspects to everyone around him, and his judgment has been thoroughly demonstrated.

Teachers who touched the lives of their students through their being role models are the ones who discovered the magic formula of raising people and leaving a lasting impact.

M. Orhan Okay has gained a respectable place in the memories of the Turkish academic world not only with his original published scientific works but also with his effort to raise "human beings" leaving a deep mark in the last fifty years of the Turkish academic world. In this article, Okay's being an ideal educator that complement his identity as an exemplary scientist was emphasized.

\subsection{Purpose of the Study}

The purpose of this study was to reveal the exemplary trainer characteristics of Prof. Dr. M. Orhan Okay, who was one of the educators who touched the lives of his students with his role modeling, and who discovered the magic formula of raising people and leaving a lasting effect, in terms of education and training activities that provided a basis for transferring emotions, thoughts and behaviors beyond the transfer of knowledge. Thus, the identity of a role model / ideal educator was revealed emphasizing Okay's being an ideal educator that completed his exemplary scientist identity.

\section{Method}

Biographical design, one of the qualitative research designs, was used in the study. In fact, this concept is a heading of various methods such as narrative, life story, oral narrative, autobiography, biography, storytelling, ethnography (Bornat, 2008, p. 344). Biographical design is a research design based on the idea of arranging, associating, and evaluating the experiences that are perceived and conveyed as important for the participant's life by researchers in a way that is meaningful for the readers (Riessman, 2008). According to Dollard (1935), life story is "... special studies that examine the development of a person in a cultural context and aim to conclude a theoretical situation." By their very nature, biographical methods encourage a universal and inclusive approach (Bornat 2008, 344). According to what Evrensel, Kakuru and Paradza express, this pattern is important in terms of revealing the participant's story from different perspectives, revealing different facts and meanings and deepening. This pattern was preferred because the ideal educator identity of Orhan Okay was tried to be examined on the basis of his biography.

\subsection{Identify Subsections}

With content analysis as one of the qualitative research methods, various magazines, books or all audio data were determined and transferred to the computer within the framework of the ideal educator identity. Similar concepts and features were categorized, and they were checked by another field expert other than researchers for reliability. In this way, the analysis of written and audio materials about the targeted phenomena and situations was made.

\section{Results}

\subsection{His Upbringing or Formation of His Character}

In this section, the multicultural environment in which the role model scientist Okay grew up, the formation and stages of his passion for reading, people who influenced him in character and academic aspects were tried to be given.

\subsubsection{Who is Orhan Okay?}

Okay, who grew up in the last generation of the Ottoman Empire in the first half of the Republic, was born on January 25, 1931 in Istanbul-Balat, as the son of Fatma Naciye Hanım from an Erzurum family and Yaşar Salih 
from an Arapgir family. Since his father was a curious person, he also wrote a note in his own handwriting on the calendar sheet of that day. This calendar was written in four cultures, with the phrase " 25 Second Law 1931" on one side, "Ramadan 1350" on the other side, " 25 Janvier" on the other side, and the expression indicating the same day in Greek on the other according to the method of those years (Karadişoğulları, 1996:58). was written. Balat was a place where the remnants of the old Byzantine and the Ottoman additions live together.

In order to present a portrait of Okay, this neighborhood is one of the most important elements that must be discussed. In Istanbul, where he was born, culture is kind of on the street; it literally flows through roads and streets. Okay opened his eyes to an environment where people who have created the colorful mosaic of this old Ottoman social structure have lived their own beliefs and cultures in peace. This experience seems to be one of the elements that explain the peaceful character of his personality (Kahraman, 1996). However, the striking point is that this pacifism involves protecting one's own beliefs and culture, at least mentally, without any complexity.

\subsubsection{How did His Literature Taste Start?}

Okay was able to read before starting school. He followed the Yavrutürk magazine published in that period. He even issued a handwritten magazine at home imitating the magazine. Turkish and literature lessons have always been good in every grade starting from the primary school. Hüseyin Bey, the owner of Yildız Bookstore, where he bought Monte Kristo novel forms in secondary school, became the first bookstore he knew (Karadişoğulları, 1996). He later discovered the second-hand booksellers.

\subsubsection{A Poor but Colorful Childhood}

The knowledge that Okay played games such as tipcat, corner grabbing, leapfrog, playing tag, prisoner, mayna, hoop, mile (marble), lover, football, thief-cop in his childhood made us think that he had a colorful childhood with a rich repertoire of games. In addition, war games played with wand horses and wooden guns, influenced by cowboy movies, should be added to the list. Okay understood that when someone was called "olmen" during a game meaning that that person was caught, that was a word taken from French films, when he heard children playing in Luxembourg Park in France, where he went in the 1960s, said "Haut les mains! (Hands up!)" to each other (Okay, 2009, p. 125).

Okay was one of the lucky kids who made his own toys. Everything that was not used in the house could turn into a toy on its own. Spinning tops, trains, and towers were made from wooden spools. Matchboxes and small bottles were also useful materials for toy invention. There were cars made of tin among the ready-made toys bought from outside are. One of favorite toys of Okay were goldfinches that moved hitting their beaks when they were set with a key and were beautifully painted and made of tin. Okay and his friends could only watch the imported toys of the Japanese store in Beyoğlu on its showcase (Okay, 2009). The toys made by Eyüp toy makers from cardboard and wood fell on their share. Owning expensive toys required financial opportunities in those times.

Among Okay's childhood memories, swings, ferris wheels, carousels set up in the feast places, cotton candy, pastes, tours thrown on donkey's back, cinema machines where movies were watched through turning by hand and oil lamp nights had a special place (Şimşek, 2018).

\subsubsection{Important Persons Whom He Felt to Recognize as Luck}

There were important personalities who were influential in the formation of Orhan Okay's character and contributed to his spiritual education. Nurettin Topçu and Abdülaziz (Bekkine) Efendi, whom he was close to when he was in his last year of secondary school, were among these names. Both played a big role in his life as the people who opened up his horizon. In 1948, Okay recognized M. Celaleddin (Ökten), an extraordinary figure and a true scientist, who taught him Arabic lessons in the first years of high school, and Mehmet Kaplan, whom he felt as a teacher until his death, thanks to his teacher of literature Behice Kaplan in his senior year. Mahmut Celal Ökten wandered İstanbul inch by inch for Turkey's first Imam Hatip high school to be opened in Istanbul in 1951 with future promising Turcology 1st grade student Orhan Okay in order to find suitable premises and he will assume the founding directorship of the school, which started education in the old building opposite Vefa High School in Fatih (Karadişoğulları, 1996).

Okay, in 1948, followed the Mesnevi lectures given by Tahirü'l Mevlevi (Tahir Olgun) in Süleymaniye Mosque during his high school years with great curiosity and interest. He got to know Rahmi Eray, who directed intellectual, philosophical and literary discussions with great restraint during the seminars organized by the Turkish Culture Center in 1949 (Yorulmaz, 1996).

\subsubsection{An Istanbul Gentleman in Anatolia}

-From the Sources of Muslim to the Professor of Literature- 
Okay, after graduating from Vefa High School (1950), was first enrolled in the Philosophy Department of Istanbul University Faculty of Letters with great idealism. In February 1951, he was admitted to the Turkish Language and Literature Department of the Higher Teacher School. He graduated in 1955. His assistantship to the Institute of Islamic Studies, where the deputy director was Fuat Sezgin, was on the agenda. His Arabic was quite good. Sezgin had a doctorate degree on Buhari's sources, and he wanted Okay to carry out studies on Muslim's sources (Karadişoğulları, 1996). However, since Okay was a student of Higher Teachers' School, which he considered as a blessing to find a job, prevented him from being an assistant.

Okay was in Ankara-Samanpazarı between 1935-36 because his father was a police officer. After this step in Anatolian life as an Istanbul child, he was appointed to Artvin as a teacher. Then he completed his military service in Merzifon. Then he continued to carry on teaching profession in Diyarbakır with the idea of being an assistant (Karadişoğulları, September 1996). He seemed to be mentally ready to go to the district areas as he chose Higher Teacher School and his family roots were in Anatolia (Kahraman, 1996).

While working as a literature teacher in Diyarbakır, Atatürk University was established in Erzurum in 1958. Mehmet Kaplan was the first dean of the Faculty of Letters opened in this university. Upon the invitation of his teacher, he came to Erzurum on the 31st day of August 1959, as married for a month, and so the Atatürk University period which lasted for 35 years began (Karadişoğulları, 1996). He became a doctor in 1963, an associate professor in 1975, and a professor in 1988.

\subsection{Prof. Dr. Okay's Character and Academic Role Model Attitude}

In this section, the exemplary attitude and behavior of Prof. Dr. Okay Hodja to everyone in social life, especially in the school as well as outside the institution, are discussed.

\subsubsection{Exemplary Personality of a Character Monument and a Scientist}

It is a fact that there is an unexplained attraction in Prof. Okay that draws his students towards him. Sincerity, friendship, and unaccounted voluntariness play the biggest role on this (Uçman, 2017). The most striking thing about the professor in his courses is his deep tolerance towards his students, which is not easily seen by everyone, due to his deep knowledge (Tümer, 2017).

Karataş calls out to his professor as: "My dear professor, does this calmness around you never fluctuate? What does that sweet smile on your face feed on, every day? Is each strand of your hair that you comb backward every day a glazed letter sent to the past? What time is your steady walk, as the old says, goes? How does that plain and brown uniform with milk scent spread to your streak of simplicity and kindness, tolerance, modesty, and sincerity in your image? How have you been able to clear out gossip from your tongue, jealousy from your heart, ill-gotten from your stomach, and hypocrisy from your attitude? " (Karataş, 2017:68).

Although a young academician who met the teacher for the first time wanted to leave after a very short conversation, Professor suddenly said with a sincere excitement, "You go? We will have dinner with friends now, come with us" Surprising his addressee (Tökel, 2017, p. 72).

When you speak of Orhan Okay, the portrait of a decent person is remembered. The two obvious lines of this portrait are undoubtedly the sincerity whose warmth is felt at all times and the tolerance that complements it. Orhan Okay, who knows the concept of simplicity, which blossomed in Âkif's saying "I lived in silence", as a life principle, is a scientist who approaches the issue he deals with without prejudice and looks at the person he is subjected to as a friend (Tekin, 1996, p. 53).

Recognizing, talking to, sharing the same space with him, and having a conversation with an elegant, polite, decent and real Istanbul gentleman like Professor Orhan is truly a privilege and a source of pride in today's world where all human values are gradually disappearing and everything is subject to material measures (Uçman, 2017). Professor Orhan is indeed a monument of virtue, humility, dervishes, and elegancy.

\subsubsection{Human-Centered Teaching of a Professor}

In an interview, he expressed such about teaching: "how does it feel to be a teacher, teaching? We have teacher-student relationships such as teaching, motherhood, and fatherhood, sometimes more than those, from primary school to university and even life-long. Chirping, the class that turns the class into a revel, for this reason, we sometimes seem angry or get angry, then a little calmer, the ones who look into your mouth, who believe in you, not what his mother or father says, gradually obeying life, little mischief, talking with friends, even copying in a test, objections to your knowledge, ideas, even unnecessary questions to distract the lesson in classes, your anger at all this, sometimes your threats, failing the class, resentment... But when you meet after years, none of these negative feelings are left. Because they understand that our every reproach to them is the same as our behavior 
towards our own children. As in every class and profession, there is a big decrease in students over the years. However, I have no students for whom I do not feel love and compassion. I think this feeling does not exist in any other profession" (Yardım, 2017, p. 16).

\subsubsection{His Interest towards His Own and Other Studies}

Professor Okay answers a question about learning the source of his dominance in fields such as philosophy, sociology, history and fine arts as well as being a new professor of Turkish literature as:

"I know new literature as much as I know, I say that I am not fully mastered. It is a matter of interest, not the domination of other areas. I love old Turkish literature, that is, divan poetry. My interest in language is a number of issues of interest in the area of Turkey's Turkish. My interest in folk literature is nothing more than an amateur, a pleasure.

I love all branches of fine arts. Philosophy is an area that I have been interested in since my high school years, but for a compulsory reason I have moved away. I followed the lectures of two certificates, European as art history and Islamic art. I visited almost all museums with curiosity and pleasure in every city I went to in Europe, especially in Paris.

With the guidance of Sahaf Raif Yelkenci, I took calligraphy lessons from academician Halim for a long time. I also liked Turkish and western music, both from the classical field. I tried not to miss these concerts while I was in Istanbul and Paris.

My saying that there is a real university outside the university is partly because of this. I would like to say that all these interests, if I can hold a pencil today, have more or less traces in my writings. Even these half-hearted concerns have broadened my horizons and formed some light foci within me" (Karadişoğulları, 1996, p. 58).

Professor knows our old literature both literally and keeps it alive. The continent of history, which he first published with the signature of Dr. S. F. Kahyaoğlu and then included in the book of Necip Fazıl, is one of the examples of this art that can be regarded as "gems" in terms of both the word corresponds to the notion and poetry. The aruz prosody was written as fâilâtün fâilâtün fâilâtün fâilün.

\section{Erdi artık ruh sükûna derviş-i kâmil gibi}

Öldü, el açmaksızın nâdâna bir sâil gibi

Çille çille üstüne düşü mücevher târihi

"Var mı şair çilleden çıksın Necip Fazıl gibi” (1403/1983) (Okay, 1987, p. 3)

If I have to explain the professor in one word, I would say "aesthete". The professor is no stranger to any good understanding. More precisely, his heart and culture are open to all kinds of beauty ideas. Every artist, whether domestic or foreign, Eastern or Western, religious or even known with what title, has no problem in understanding and explaining the beauty in his work (Polat, 1996, p. 51).

Tümer (2017, p. 52) stated that "He had an admirable memory. He dominated the affairs of Eastern and Western civilizations in surprising details. During the moments I was with him, I witnessed that not only the researchers from Department of Turkish Language and Literature, but also from the departments such as Western Languages, Arabic Persian Language and Literature, and Theater addressed questions and he solved them with knowledge."

His engineer son Fuad Okay also said in TRT2 program of "Okudukça" that "My father had good knowledge of geometry to help me in my high school classes. He had interest in photography and an archive about it. Wherever he saw a cat, he never neglected to love." (18 July 2009).

\subsubsection{A Professor Giving Publication List to His Students}

Professor Orhan distributed a list of publications that had to be read for four years without separating the right and left in his lectures from 1970's on and explained that some books should definitely be read and some of them should be read on demand (İsen, 1996).

In order for the graduate students to be well educated, he recommended them to read some basic works without compelling before starting the study subject. Among these, there were certainly works related to philosophy, aesthetics, Islamic history, Ottoman history, and the history of science, as well as a catechism, a translation or an interpretation (Polat, 1996). For some, there were works that were marked separately in the list of books he gave. He also followed his students. 


\subsubsection{An Exemplary Educator with Way and Style of Lecturing}

In his lessons, the Professor focused on poetry and mistakes in reading and pronunciation. To Turcology students, he said, "Knowing aruz is not a virtue, not knowing is a shame." His efforts to inform his students by repeating his words were unforgettable (Tümer, 2017 p. 52; İsen, 1996, p. 37). In the lessons, Professor Orhan would open the door to the discussion and let the students talk without taking sides. Sometimes he continued his lessons meticulously without giving any opportunity (Haksal, 1996).

The generosity of the professor in sharing what he knew and the comfortable and warm communication he had with his students have been the common dreams of every teacher. He was one of the rare teachers who did not apply the dictation method adopted as a common teaching method in 1975-80. He was always standing and always making drawings showing the network of relationships on the board and writing what he wanted to emphasize. Supporting what was told in the exams with different sources was among his expectations. With such an attitude, he guided the students to both research and reading, while encouraging them to read different sources (Gündüz, 2017). He listened to his students with great patience, answered their consistent or inconsistent questions, showed the value he gave to people regardless of who they were, and definitely showed the books he mentioned in the lesson (Tümer, 2017).

The professor encouraged almost every student he saw a spark to read and do research guiding them through letters or face-to-face conversations. He used to give those precious resources to his graduate students without worrying about loss or wear out (İsen, 1996; Gündüz, 2017).

One of the unchangeable questions in his postgraduate exams was the source information. Especially during the interview exams, he wanted one of the printed and original bound books with old letters to be recognized and said something about it. Although this question method was regarded as strange by some, it was understood better in the following years that he encouraged all his students to go to the library, to read those rare books, to have them, and to at least open the cover of those books (Gündüz, 2017, p. 56).

He never compromised his scientific truths and principles. He did not hesitate to let his students fail in the exam in case of their failure, including the students he felt close to and wanted to protect.

\subsubsection{An Ideal Professor with His Scientific Stance, Attention and Diligence}

One of Okay's most distinctive features was his meticulousness, caution and attention. He reads the articles presented to him carefully underlining some of the statements and without hurting stating that "These are not bad, go ahead." This attitude was a beautiful lesson in literature and life. Against the thoughts put forward with an ignorant courage, he would say, "Stop, do not rush, let's think, maybe, but let's see." He remembered the smallest detail, gave information, and completed the missing information. Despite knowing so much, he could easily say "I don't know", which expression was half the science. He was able to show the same seriousness, the same stance, and the same primitiveness in front of everyone, everywhere, and at any time (Karataş, 2017, p. 68; Haksal, 1996, p. 45). He also attached great importance to knowledge, discipline, and meticulous work. He was the best example in this regard. He carried on studies systematically and created information and book slips, although it was laborious (İsen, 1996; Tümer, 2017).

His students learned from the examples of scientific doubt he demonstrated, what surprises they might face when they once again checked information that seemed never to be discussed in a text (İsen, 1996:37). Being objective in scientific matters, helping the person to be evaluated only as much as he deserved was the leading of all traits witnessed in him.

In his first postgraduate course, the subject that the professor focused on was the ethics of science that he exemplified personally. The fact that he taught all kinds of sharing, reinforced friendship and solidarity among his students, and not to confuse personal interests with scientific affairs were the clues of his academy ideal (Tümer, 2017).

Every teacher did his best to ensure that his students were well educated. But Professor Okay's effort was for his student aimed them to surpass him. He gave his works on subjects that he did not have time to write to his students together with the material in his personal library without feeling jealous, instead as a matter of great pleasure taking a note (Polat, 1996). A greater moment of pleasure and joy was to see and read the article he recommended as written.

Every teacher has done their best to ensure that their students have been well educated. But Professor Okay s effort for his students was to surpass him. He gave his works on subjects that he did not have time to write to his students, together with the material in his personal library, without feeling jealous or even as a matter of great pleasure taking notes (Polat, 1996). A greater moment of pleasure and joy was to see and read the article he recommended 
as written.

Many lecturers in the academic world have been diggers of their own blind wells, and they have been blind of other wells. It was not possible to see this infertility in this professor (Tökel, 2017). The professor, who has always been humble and cautious about life, did not highlight the wealth behind his personality and did not want to give himself away (Haksal, 1996, p. 45). He became an older brother to the successors.

Academicians of various degrees, students, graduate or doctoral students, even the readers of the professor, journalists, television interviewers who came to interview ... It was not the case that the professor turned anyone down who came to meet him or demanded something from him (Uçman, 2017). One of the aspects about him was that he opened his house especially for graduate students to evaluate their studies when necessary (Tümer, 2017).

The way he encouraged each student to read and write, his ability to criticize his writings to be good and right, to motivate his students by always looking at the positive aspects of what they did, to show them their mistakes indirectly showing good examples, and his generous presentation of different professors' sides were magnificent examples showing his scientist side (İsen, 1996).

\subsubsection{Idealist Scientific Mentality}

Regarding Beşir Fuat, whose doctorate subject was far from himself in terms of his world view and seemed to him a marginal and even paradoxical person, he said "In my eyes, there is no antipathy or sympathy in scientific research. In this respect, there is no difference between raising the person we love and hitting the one we do not love to the ground. It doesn't matter if you like the person you are studying or not, the important thing is to love the subject. I also liked the subject and I think I approached it with an idealistic scientific mindset" (Karadişoğulları, 1996, p. 58).

It was seen that in Professor Orhan's articles, as in his lectures, ideological codes, world understanding, and personal value judgments were significantly excluded (Gariper, 2017). As a literature professor and researcher, he preferred to act in an effort to ensure that the artists or works of the period which he dealt with were understood in their own reality.

\subsubsection{An Instructor Without a Dull Moment}

Those who have reached the proficiency of being an undergraduate, graduate, and doctorate student of the professor left learning something whenever they were with him in his classroom, room, house, or a restaurant. They hadn't seen a single wasted minute. They hadn't heard a single sentence that did not teach or inspire anything. He enlightened a scientific and social issue with his speech and taught politeness with his silence (Polat, 1996; Tümer, 2017).

When he visited his graduate students' home, he examined the humble library at their home and asked questions about the content of the books. He used to pay attention to whether the places of the books had changed in his different visits (Gündüz, 2017, p. 56).

Since Professor Orhan was an innate educator, he believed that the most important investment would be on people. Because he was aware that man was the greatest work of the Greatest Artist.

\subsubsection{Writing in Two Styles}

In one of his interviews, he said about his articles that "My articles are of two types. One is a style that does not allow any deviation, bending, or even personal consideration, maybe even interpretation, and leaves no door ajar.

In the second, I am open to considerations such as experimentation, comments, even opinions, sentimental approaches, indemnities, and impressions. Of course, I tried to put on a solid ground for the scientific and objective information in these kinds of writings. What is important in both ways is that this should be honest in scientific and objective information, it should not be hidden, it should be presented without causing blur" (Karadişoğulları, 1996, p. 58).

\subsubsection{The Writing World of a Model Scientist}

Okay had generously written down his knowledge and knowledge. One of the important pieces of evidences of his personality that symbolized the exemplary scientist was his studies. Unlike some of the professors who have been well-equipped but who have written little, he passed away after revealing his knowledge with his writings (Haksal, 1996, p. 45).

Apart from the articles and various articles he left behind, he had many books that contained research, analysis, and determinations directly related to the field of memory, essay, travel, and more. Especially his memoirs completed the true intellectual mission of the Turkish nation depicting many issues that the 3rd generation of the Republic has 
been foreign, incomplete, or wrongly aware of, in a warm and plain style.

\subsubsection{Recommendations of the Researcher}

Okay had important advice to young generation academics on issues such as reading awareness, research discipline, and working style:

"There is a fact that everyone accepts, this generation does not read. My recommendations based on these will be as follows:

First, they should have a good library. It should not be forgotten that the books in public libraries are not ours, they should always feel the security that a library at our disposal and in front of our eyes will give them. It seems that the needs of the modern world have increased, namely a house, a car, and other needs, we should not forget the need of our soul.

Second, let them start writing their knowledge and thought at a young age. Writing habit is a very important gain for a researcher.

Third, those working in the same or different fields should cooperate. They both consult each other and give the information they obtain to their colleagues without even the feeling of sacrifice. Then they can work together and work in teams.

Finally, my last piece of advice is not to limit themselves to tight spaces where they work alone. More than any other field of research, literature requires contact with other fields. In this age of expertise, I do not mean to know everything. The point is to be in the way of interest or knowledge. If our topic is New Literature, they should expand the circle of interest and place the old literature, the literatures of the Eastern and Western nations, history, philosophy, sociology, psychology, other fine arts at some points of these intertwined circles" (Karadişoğulları, 1996, p. 58).

According to Okay, our attention should focus on national resources, the basic values that our civilization and national culture came into being, the religion, morality, worldview, understanding of beauty that made our nation, and the way of life created by all these, our human values that emerged with our relations with other people and all our works of art, especially literature (Korkmaz, 2017).

\subsubsection{The Professor Who Knew and Taught the Aruz Rhythm Best}

Professor Okay made some applications to examine the musical ear and rhythm perception of graduate and doctoral students. He handed out a poem written with prosody and asked them to read the meter in a vaguely heard but natural tone.

Okay regarded aruz as a culture, not as a "mold". According to him, no matter how much the poem changed, someone who took the prosody culture could benefit from that culture in all kinds of poetry. Just as a modern piece of music has enriched the piece entering a section from Itrî. For Okay, prosody constituted an important part of the musicality in poetry.

Professor Okay gave prosody lessons at Kubbealtı Academy after retiring and settling in Istanbul. It was surprising for the Professor that not only students and lecturers of the faculty of literature, but also architects and engineers continued his lessons. He thought this was due to an extreme curiosity. He knew that those who took lessons would not write poems with prosody. He said that "It is not possible for prosody to survive in the classical sense. It will probably remain a fantasy" (Şimşek, 2018, p. 42).

The duration of the Aruz lessons was 14 weeks. In teaching of aruz, the method of memorization is generally used. Those who attended Professor Okay's lectures did not memorize. Professor said, "There is no need for memorization. They just need to hear that music by ear. Among the poets of Divan, there are those who write with prosody without knowing it. But it takes a lot of work, just like learning to play an instrument."

The teacher's recommended his students "to study for at least five hours on their own for an hour of lesson." He believed that it would be possible to read Fuzuli, Baki, even Yahya Kemal and Ahmet Haşim more accurately (Şimşek, 2018, p. 42).

\subsubsection{Loyalty Indicators}

In the words of Orhan Kemal Tavukçu, the pictures of Celal Hoca and Topçu on the wall of his room (which he hanged on the most elegant corner of his wallet) draw attention, in case of taking a photo with him (İsen, 1996; Yorulmaz, 1996; Tökel, 2017).

The objects in the background of a photo of Professor Orhan and his wife Mübeccel Hanım taken in a one-room 
house in Paris (Bir Başka Paris, p. 24) was striking: A shelf in the upper right corner and the Koran on the shelf, in the middle and Karahisari besmele on the same line, below the Turkish flag, a radio bought from Paris, to the left of the radio is the postcard of the Double Minaret Madrasa in Erzurum ... (Şimşek, 2017). This painting reflected the wealth and the world of values the Okay family took with them on their way to Paris.

\subsubsection{An Istanbul Gentleman's View of the World/World Goods}

As a true "Istanbul gentleman" rather than just a principled word, "moderation" seems to suit him the most. He did not care for the extremes and did not aspire to be the man of the day. Despite being very insistent, he denied the positions such as department head, director, and dean politely saying, "I can't" (Karataş, 2017, p. 68).

He liked to walk and never wanted to have a private car. He established a discreet relationship with the world and living (Karataş 2017). When asked whether his salary was enough after his retirement in 1996, he said, "The state pays me this amount of pension, sir. We are just two, what are we going to do with this much money" (Tökel, 2017, p. 72). The professor focused on beauty and competence in the field of being; not deficiency, scarcity, failure. He was one of the great people who diminished himself within the boundaries of existence, he added meaning, value, beauty, and difference to his existence rather than disappearing, and he saw what existed.

\subsubsection{His Professional Behavior in Social Relations with Course Relationship}

When one of his students suffering from financial difficulties applied only to attend the exams, Okay looked in the eyes of his student and stated that he could not let this with a kind but bitter expression after pausing for a while. The student cannot be angry with that awkward look that refused his request. A day later, Professor Orhan and a friend talked, and the professor arranged a scholarship for him from the Assistants Association (Haksal, 1996, p. 45). After that, he took special care when he went to the professor for a scholarship every month.

At the end of the summer of 1994, the Professor was sent off to Istanbul to work in Sakarya from Erzurum, where he worked with his wife as an academic for 35 years. At one point, the Professor cautioned his colleague a student aside, "You know, there are students that we try to contribute in various departments, we will send you and you will give to them until they graduate" (Arslan, 2017, p. 27).

\subsubsection{Social Surrounding and Family Relationships}

Okay, in his social relationships, often with his behavior, he was an excellent educator with his insinuations or suggestions he made without offending or hurting anyone, and with his graceful humor and jokes.

In his family life, as well, he was a loving, exemplary husband and a perfect father for his children. There were witnesses that he maintained this feature patiently and without losing anything from his love during his wife's long illness (Gündüz, 2017).

\section{Discussion}

Prof. Dr. Okay grew up in a multicultural environment in Istanbul. This situation has given him a wide range of tolerance and perspective. He was not contented with the education he received in schools, but he also grew up by taking lessons in different fields. In this upbringing, both cognitive and affective, and behavioral aspects of him have also matured. He benefited from the people he considered ideal not only in terms of knowledge but also in terms of behavior. Likewise, his students and those around him acquired examples from him both academically and in terms of human values through observation, imitation, and internalization. Among these behaviors, the followings can be stated; understanding of the academic discipline, mastery of interests, sensitivity to close fields, not confusing academic duty with humanitarian, objectivity towards everyone, unique tolerance, material and moral aid to those in need, being ambitious in science but not indulging in property, not accepting any administrative duty with the thought of not hindering academic studies.

He said, "I became a part of the people I had the luck of. I wanted to be Tanpinar with the association of literature and art, and became M. Kaplan, the paper man who conveyed what he knew with sound knowledge." (TRT2 "Okudukça", 18 July 2009).

Okay had become such a loyal husband that his wife Mübeccel Hanım said in a speech, "If someone were to be worshiped in the world, I would be a servant to Orhan" (Karataş, 2017, p. 68).

It is possible to say that the image of a rare person, a distinguished scientist, cultural and artistic man, a spiritual architect, and an "ideal professor" at the university who instilled not only a curiosity for learning but also science morality and taught grace, grace, and humility, Orhan Okay passed away on 13 January 2017 (Gündüz, 2018). He left hearts full of gratitude who imitated his idealism and students who were determined to transfer his gifts behind him. As one of his students has mentioned there are people who learn a lot from him and realize how important it is to follow his path. 


\section{References}

Arslan, M. A. (2017). Orhan Okay özel sayı. Mahur Beste, 2, 23-27.

Aydınay Satan, A. (2015). Değerler ve eğitimi II. İstanbul: Dem Yayınları.

Bacanl, H. (2007). Değer ve eğitimi - Bilişsel ve duyuşsal hedefler bir model önerisi. İstanbul: Dem Yayınları.

Bandura, A. (1977). Social learning theory. Englevood Cliffs, NJ: Prentice-Hall.

Bandura, A. (1999). Social cognitive theory: An agentic perspective. Asian Journal of Social Psychology, 2, 21-41. https://doi.org/10.1111/1467-839X.00024

Bell, A. P. (1970). Role modelship and interaction in adolescence and young adulthood. Developmental Psychology, 2, 123-128. https://doi.org/10.1037/h0028613

Boran, A. (2014). Değerler eğitiminde öğretmen yeterlikleri-Felsefe-edebiyat ve değerler. Ankara: Öncü Basımevi.

Bornat, J. (2008). Biographical methods. In P. Alasuutari, L. Bickman, \& J. Brannen (Eds.), The sage handbook of social research methods (pp. 344-356). London, UK: Sage. https://doi.org/10.4135/9781446212165.n20

Deal, T. E., \& Kennedy, A. A. (1982). Corporate cultures: The rites and rituals of corporate life. Massachusetts: Addison-Wesley.

Dollard, J. (1935). Criteria for the life history: With analysis of six notable documents. Yale University Press. New Haven. https://doi.org/10.1037/10755-000

Elkatmış, M. (2016). Farkl yönleriyle değerler eğitimi: Okul kültüründe demokrasinin yeri. Ankara: Pegem Akademi.

Erikson, E. H. (1950). Childhood and society. New York: W.W. Norton.

Erikson, E. H. (1985). Childhood and society (35th Anniversary ed.). New York: W.W. Norton.

Erverdi, E. (drl.) (2011). Orhan Okay kitabı. İstanbul: Dergâh Yay.

Flum, H. (2001). Relational dimensions in career development. Journal of Vocational Behavior, 59, 1-16. https://doi.org/10.1006/jvbe.2000.1786

Foote, N. N. (1951). Identification as the basis for a theory of motivation. American Sociological Review, 16, 14-21. https://doi.org/10.2307/2087964

Gariper, C. (2017, March). M. Orhan Okay'ın ardından. Türk Edebiyatı, 521, 46-51.

Gibson, D. E. (2004). Role model in career development: New direction for theory and research. Journal of Vocational Behavior, 65, 134-156. https://doi.org/10.1016/S0001-8791(03)00051-4

Girona, J. P. (2002, August 1). Finding role models for youts in Palm River goal of MAD DADS. The Tampa Tribune (p. 1).

Gündüz, O. (2017, March). M. Orhan Okay'nn ardından. Türk Edebiyatt, 521, 56-58.

Gündüz, O. (2018, January). M. Orhan Okay Paneli (Yöneten: M. Hanefi İspirli, Konuşmacılar: Osman Gündüz, Mehmet Törenek, Tacettin Şimşek, İsmail Bingöl). Türkiye Yazarlar Birliği Erzurum Şubesi, Atatürk Üniversitesi Mavi Salon.

Haksal, A. H. (1996, September). Orhan Okay Hoca'ya saygıyla. Yedi İklim, 78, 45-50.

Hiralaal, A. (2018, December). Exploring my role modelling as a teacher educator: A self-study. South African Journal of Higher Education, 32(6), 619-634. https://doi.org/10.20853/32-6-3001

Hökelekli, H. (2011). Ailede, okulda, toplumda değerler psikolojisi ve eğitimi, değerler eğitimi ile ilgili bazı tespit ve öneriler. İstanbul: Timaş Yayınları

İsen, M. (1996). Orhan Okay Hoca'ya saygiyla. Yedi İklim, 78, 37-39.

Kahraman, A. (1996). Orhan Okay Hoca'ya saygiyla. Yedi İklim, 78, 30-33.

Kahraman, A. (2017). Tanıdı̆̆ım Orhan Okay Fotoğrafta Kalan Anılar. İstanbul: Büyüyenay Yay.

Kakuru, D. M., \& Paradza, G. G. (2007). Reflections on the use of the life history method in researching rural African women: field experiences from Uganda and Zimbabwe. Gender \& Development, 15(2), 287-297.

Karadişoğulları, E. (1996). Orhan Okay Hoca'ya saygıyla. Yedi İklim, 78, 58-66. 
Karataş, T. (2017). M. Orhan Okay'ın ardından. Türk Edebiyatı, 521, 68-71.

Kaymakcan, R., \& Meydan, H. (2016). Ahlak değerler ve eğitimi. İstanbul: Dem Yayınları.

Kirschenbaum, H. (1994). 100 Ways to Enhance Values and Morality in Schools and Youth Settings. Allyn\&Bacon, Old Tappan, New Jersey.

Kohlberg, L. (1981). The philosophy of moral development: Moral stages and the idea of justice. San Francisco: Harper \& Row.

Korkmaz, R. (2017). M. Orhan Okay'ın ardından. Türk Edebiyatı, 521, 40-42.

Lickona, T. (1991). Educating for character: How our schools can teach respect and responsibility. New York: Bantam.

Lockwood, P., \& Kunda, Z. (1997). Increasing the salience of one's best selves can undermine inspiration by outstanding role models. Journal of Personality and Social Psychology, 76, 214-228. https://doi.org/10.1037/0022-3514.76.2.214

Lumpkin, A. (2008). Teachers as role models teaching character and moral virtues. Journal of Physical Education Recreation \& Dance, 79(2), 45-50. https://doi.org/10.1080/07303084.2008.10598134

Okay, O. (1969). Beşir Fuad: İlk Türk pozitivist ve natüralisti. İstanbul: Dergâh Yay.

Okay, O. (1987). Necip Fazıl Kısakürek. Ankara: Kültür Bakanlığı Yay.

Okay, O. (1991). Kültür ve edebiyatımızdan-makaleler, denemeler, sohbetler. Ankara: Akçağ Yay.

Okay, O. (1998). Konuşmalar, mülâkat, sohbet, anket, açık oturum. Ankara: Akçağ Yay.

Okay, O. (2002). Klsakürek, Necip Fazıl. TDV İslâm Ansiklopedisi. Ankara: TDV Yayınları.

Okay, O. (2009). Balat. İstanbul: Heyamola Yay.

Okay, O. (2012). Bir başka İstanbul. İstanbul: Kubbealtı Neşriyat

Okay, O. (2013). Bir başka Paris. İstanbul: Dergâh Yay.

Okay, O. (2013). Kâğıt medeniyeti. İstanbul: Dergâh Yay.

Okay, O. (2013). Silik fotoğraflar, portreler. İstanbul: Dergâh Yay.

Okay, O. (2015). Anadolu'dan hatıralarla Nurettin Topçu'nun mektupları. Ankara: Cümle Yay.

Okay, O. (2015). Mehmet Kaplan'dan hatıralar, mektuplar. İstanbul: Türk Edebiyatı Vakfı Yay.

Orhan Okay’a Armağan. (1997). İstanbul: Dergâh Yay.

Polat, N. H. (1996). Orhan Okay Hoca'ya saygiyla. Yedi İklim, 78, 51-53.

Riessman, C. K. (2008). Narrative methods for the human sciences. Sage.

Rust, F. O. (2019). Redesign in teacher education: the roles of teacher educators. European Journal of Teacher Education, 42(4), 523-533. https://doi.org/10.1080/02619768.2019.1628215

Rutledge, K. (2000). Social Learning Theory - Notes on Ormond's Psychology of Learning. 13 Ocak 2004'te indirildi.

Sharma, M. (2020). Teachers education and its perspective. Solid State Technology, 63(6), 9845-9853.

Şimşek, T. (2017). Orhan Okay'ın objektifinden Paris. Türk Edebiyatı, 521, 42-45.

Şimşek, T. (2018). M. Orhan Okay Paneli (Yöneten: M. H. İspirli, Konuşmacılar: O. Gündüz, M. Törenek, T. Şimşek, İ. Bingöl). TYB Erzurum Şubesi, Atatürk Üniversitesi Mavi Salon.

Şimşek, T. (2018). Orhan Okay'ın Balat'ı. TYB Akademi, 22.

Tekin, M. (1996). Orhan Okay Hoca'ya saygiyla. Yedi İklim, 78, 53-57.

Tökel, D. A. (2017). M. Orhan Okay'ın ardından. Türk Edebiyatı, 521, 72-77.

TRT2. (18 July 2009). Okudukça. Orhan Okay Özel Bölüm.

Tümer, C. Ş. (2017). M. Orhan Okay'ın ardından. Türk Edebiyatı, 521, 52-53.

Uçman, A. (2017). M. Orhan Okay'ın ardından. Türk Edebiyatı, 521, 22-28.

Ulusoy, K., \& Dilmaç, B. (2012). Değerler ĕgitimi. Ankara: Pegem Akademi Yayınları.

Veugelers, W. (2000). Different Ways of Teaching Values. Educational Review, 52(1), 37-46. 
https://doi.org/10.1080/00131910097397

Wood, R., \& Bandura, A. (1989). Social cognitive theory of organizational management. Academy of Management Review, 14(3), 361-384. https://doi.org/10.5465/amr.1989.4279067

Yardım, M. N. (2017). M. Orhan Okay'ın ardından. Türk Edebiyatı, 521, 16-19.

Yiğitbaş, M., \& Çelikörs, S. (Eds.) (2018). Orhan Okay Özel Sayısı. TYB Akademi (S. 22).

Yıldırım, A., \& Şimşek, H. (2011). Nitel Araştırma Yöntemleri. Ankara: Seçkin Yayınları.

Yorulmaz, H. (1996). Orhan Okay Hoca’ya saygıyla. Yedi İklim, 78, 39-44.

\section{Copyrights}

Copyright for this article is retained by the author(s), with first publication rights granted to the journal.

This is an open-access article distributed under the terms and conditions of the Creative Commons Attribution license (http://creativecommons.org/licenses/by/4.0/). 